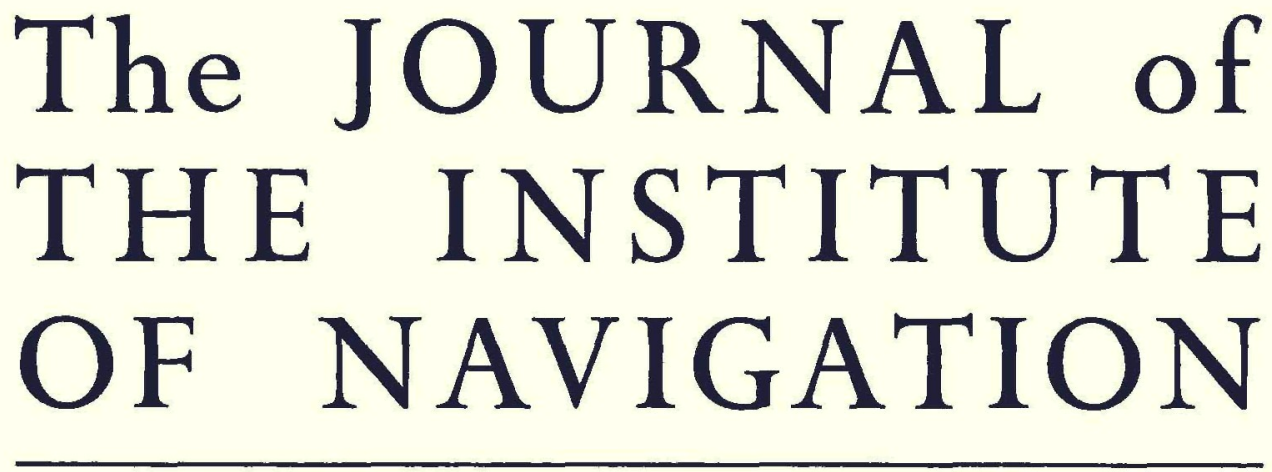

VOL. 23, NO. 3

J ULY

1970

Guidance and Control Philosophy for All-weather Landing

S. S. D. Jones

A Two-component Electromagnetic Ship's Log

M. J. Tucker, N. D. Smith, F. E. Pierce and E. P. Collins

Velocity Measurement in Tanker Berthing

P. J. Bulman

Operational Research and Cost Benefit Analysis on Navigation

with Particular Reference to Marine Accidents

A. Stratton and W. E. Silver

The Search for Minerve

INGÉNIEUR HYdROGRAPHE EN ChEF J. PASQUAY

A Three-dimensional Simulator for Mancuvring of Surface Ships 348

J. D. van Manen And J. P. Hooft

The New Reach in Navigation at Sea

R. B. RICHARDSON

The Cumulative Turn

F. C. BELL

FORUM

Reversal of the Traffic Flow in the Dover Strait

- L. Ouder

An Examination of some Ship Radars with Automatic Computation F. J. WYLIE

Spherical Triangles with Integral-degree Parts

D. H. SADLER

Simplified Tidal Calculations

A. N. BLACK

Revised Rules for Preventing Collisions at Sea J. Garcta-Frías

The Collision Problem and Manceuvring by Stages

J. Garcfa-Frias

Metrication and the Nautical Mile

R. TURNER

Record

Reviews

THE INSTITUTE OF NAVIGATION

AT THE ROYAL GEOGRAPHICAL SOCIETY I KENSINGTON GORE LONDON SW 7

JOHN MURRAY (PUBLISHERS) LTD., so ALBEMARLE STREET, LONDON wi 


\section{THE INSTITUTE OF NAVIGATION}

\section{Patron \\ H.R.H. THE PRINCE PHILIP DUKE OF EDINBURGH, к.G., к.T., о.м. \\ OFFICERS AND COUNCIL 1969- 70}

President

A. Stratton

Vice-Prestdents

G. E. Beck

Rear Admiral G. S. Ritchie, C.B., D.s.c.

Honorery Treasurer

F. A. Haworth

Chairman of the Technical Committee

Dr. G. E. R. Deacon, C.B.E., P.R.s.

Chairman of the Membership and Fellowship Comoittee

Captain V. A. M. Hunt, c.B.E.

J. H. Beattie

W. O. Broughton

W. J. Charmley

Captain C. H. Cotter

Group Capt. D. F. H. Grocott, C.B.E., A.P.C.
Other Members of Council

Captain R. Hart, c.B.B., D.8.o., D.s.c.

G. A. B. King

Captain F. L. Main

H. E. Smith

R. Whalley

Executjre Secretary: M. W. Richey, M.B.E.

\section{The Journal of the Institute of Navigation}

Tre journal is published quarterly by the Institute and is edited by M. W. RuchEY. It contains original papers contributing to the science of navigation, including those presented at meetings of the Institute together with the ensuing discussion. In addition the journal includes a record of current navigational work, reviews of important books, and other matters of concern to those interested in navigation. The views expressed in the Journal are not necessarily those of the Institute, or of any organization or department to which the authors may belong. In the case of some papers Crown Copyright may be reserved.

The Journal is issued free to all members of the Institute. It is sold to the public at thirty shillings per copy or, by subscription, at one hundred and twenty-five shillings per annum (post free) and may be obtained through all booksellers and John Murray (Publishers) Ltd., 5o Albemarle Street, London WI.

Contributions, which are welcomed from both members and non-members, should be addressed to the Editor.

Enquiries for advertising space should be addressed to the Institute offices.

The postal address of the Institute is:

The Institute of Navigation, at The Royal Geographical Society, I Kensington Gore, London SW7 


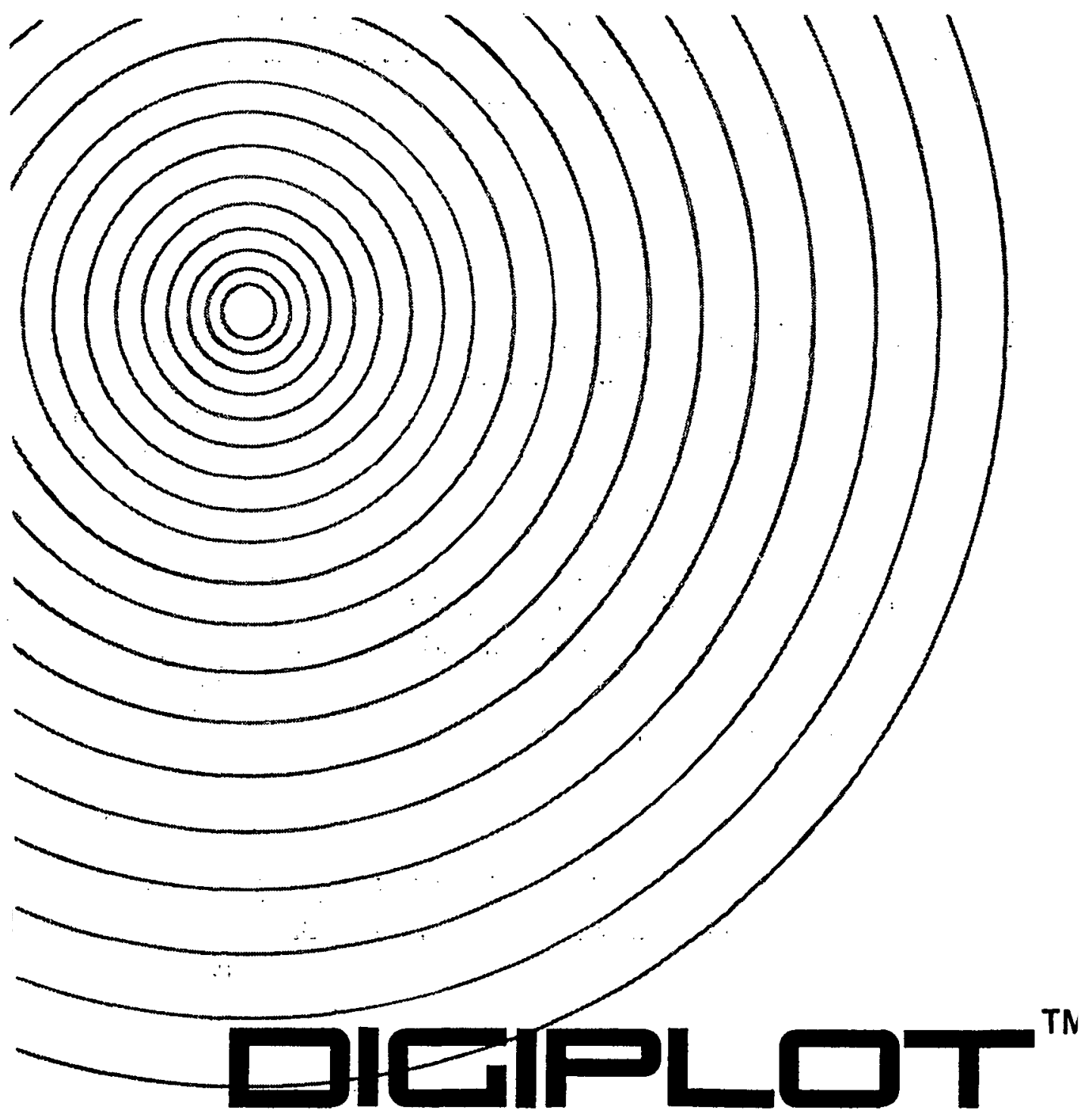

DIRECT INQUIRIES TO:

IOTRON CORPORATION

7 ALFRED CIRCLE

BEDFORD, MASSACHUSETTS U.S.A.

CABLE: IOTRON BOSTON 


\section{USEFUL BOOKS ON NAVIGATION AND SHIPPING LAW}

\section{MICHOLLS'S SEAMANSHIP AND NAUTIGAL KNOWLEDGE}

By CHARLES H. BROWN, F.R.S.G.S., Extra Master 55/-

Per post 59/6

Supplement $4 /-$

Per post $4 / 6$

\section{NICHOLLS'S CONGISE GUIDE}

Vol. I. Fundamental Principles and Second Mates

Revised. By H. H. BROWN, D.Sc., R.D., Extra Master

$601-$

Per post 64/6

Vol. II. Mate, Master and Extra Master

44/-

Per post $48 / 6$

\section{A HISTORY OF THE PRAGTIGE OF NAVIGATION}

By J. B. HEWSON, F.R.G.S., R.D., R.N.R. (Retd.). 40/-

Per post $44 / 6$

\section{LAW AND PRAGTICE OF SEA TRANSPORT}

By CAPTAIN L. F. H. STANTON, A.M.Inst.T. $63 /-$

Per post 66/-

\section{BUSINESS AND LAW FOR THE SHIP MASTER}

By CAPTAIN F. N. HOPKINS, M.I.N., Extra Master 90/-

Per post $94 / 6$

Supplement 5/-

Per post 5/6

Catalogue " $N$ ", giving further titles and details, free on request.

\section{BROWN, SON \& FERGUSON, LTD.,}

52. DARANEX STRRET, GLASGOW; S.1. 


\section{Kelvin Hughes for the wide ocean spaces (and very narrow waterways)}

A complete range of equipment for navigationfish detection and special applications

\section{KELVIN HUGHES}

New North Road, Hainault, Ifford, Essex.

Tel: $01-5001020$

London Showroom:St.Clare House, Minories, E.C.3. $8 \%$ 


\section{'NAVIGATION, U.S.A.'}

Nevigation, the quarterly Journal of the American Inatitute of Navigation, is avallable to meabers of this Institute at a reduced subscription of $f 2$ a year. Volume 17, No. I (Spring 1970) conteins the following papers.

EARLY HISTORY OF DEEP SUBMBRGBNCE NAVIGATION ABOARD TRIESTB

Kennath V. Mackentic

MARITIME AIDS TO NAVIGATION IN THE SHORT DISTANCB MARITIME ENVTRON-

MENT

Capt. D. Dulany Claggett, U.S.N. (Rat.)

ONE-WAY RADIO RANGE MEASURBMENTS FOR SURVBYTG AND NAVIGATION Dr. H. C. Freiesleben

INTEROCBANIC CANAL STUDIBS

George A. Makela and Bdwin W. Eden, Yr.

AUTOMATIC PLOTIING AND ANTI-COLLISION WARNING SYSTBM

Aldo Massara

LONG PERIOD BRROR MODES OF A DOPPLER RADAR/FREE DIRECTIONAL GYRO NAVIGATION SYSTBM

F. C. Sakean, Fi.

THB OPFSET MBTHOD OP SONAR RANGING

D. B. Boegeman

PRACTICAL BXPERIBNCE WITH SATELIITE NAVIGATION ABOARD USNS CHARLBS H.

DAVIS (T-AGOR S)
E. C. Buffington, K. H. Hughes and D. W. Muerdier

SIDB-IOOKING SONAR NAVIGATION

Dr. Carl D. Lowonstein

PRECISION POSITION MEASUREMENT FOR SURFACE SHIPS UTILIZING SHORT PULSE MICROWAVE TRANSMISSION

Philip N. Migdal and Arthur Y. Mantum

A DEEP SUBMBRGENCE DIVBRS NAVIGATION SYSTBM Ben Salezat

FLIGHT TEST BXPERIMENTS TO EVALUATB AIDED-INERTIAL SYSTEM PBRFORM-

ANCB FOR TBRMINAL GUIDANCE

Ronald Y. Madigan

THB INSTITUTE'S PROFESSIONAL FILE

Reviews of Recent Books

\section{ROYAL GEOGRAPHICAL SOCIETY}

\section{NEW GEOGRAPHICAL LITERATURE AND MAPS}

\section{HALF-YEARLY ACCESSIONS TO THE SOCIETY'S LIBRARY AND MAP ROOM}

ANNUAL SUBSCRIPTION: $f_{3}$ (U.S.A. \$8.50) post free from the Office of the Society.

This, the only current British printed bibliography of geography and cartography, has now completed eighteen years of publication.

Each number includes not only new books but also papers selected from about 130 periodicals in all the principal languages.

The map section includes all new atlases and maps received by the Society.

For the use of Libraries, an edition on gummed paper is also available, price $£^{3}$ for one copy. 


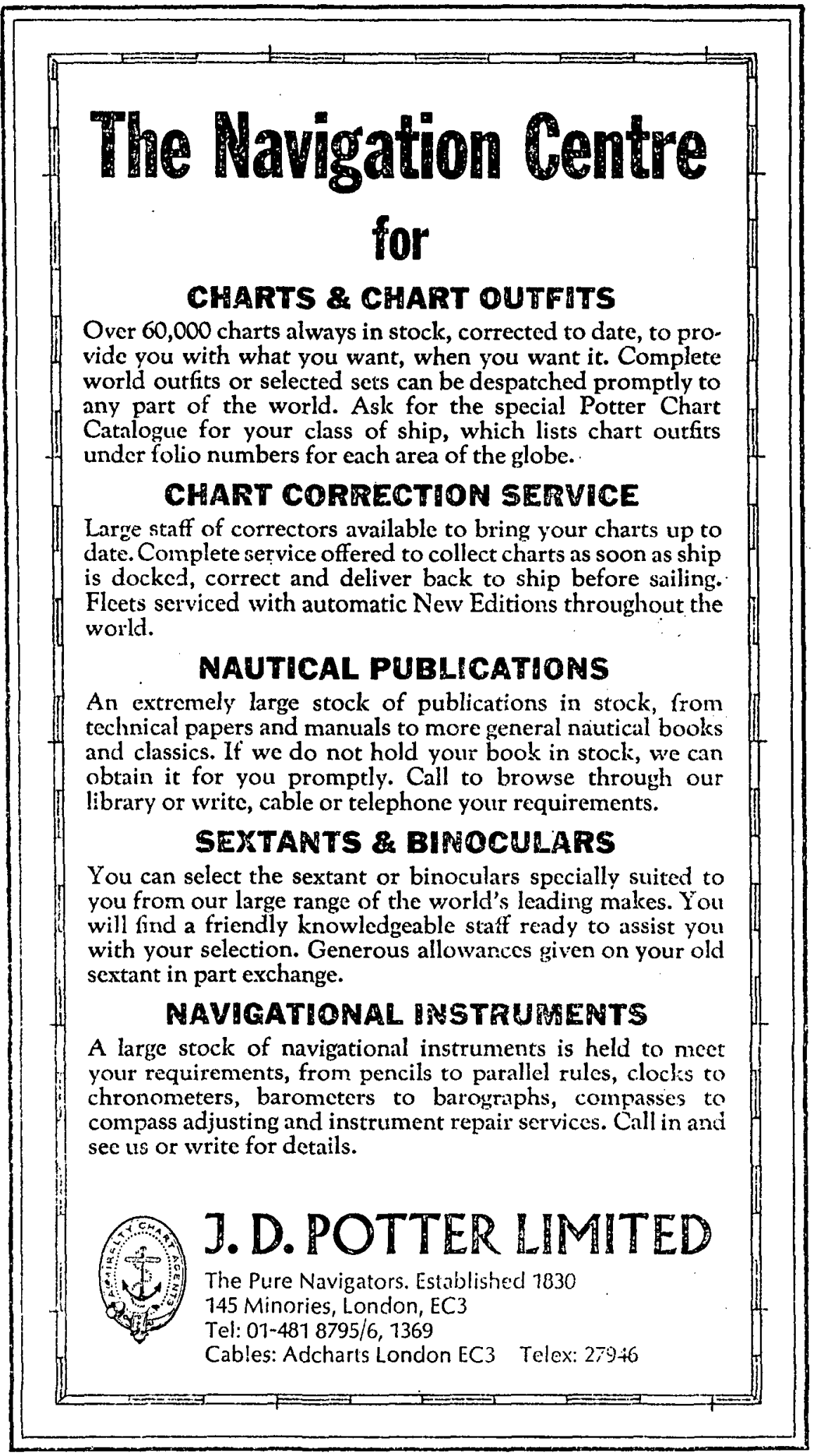




\section{true 91x?}

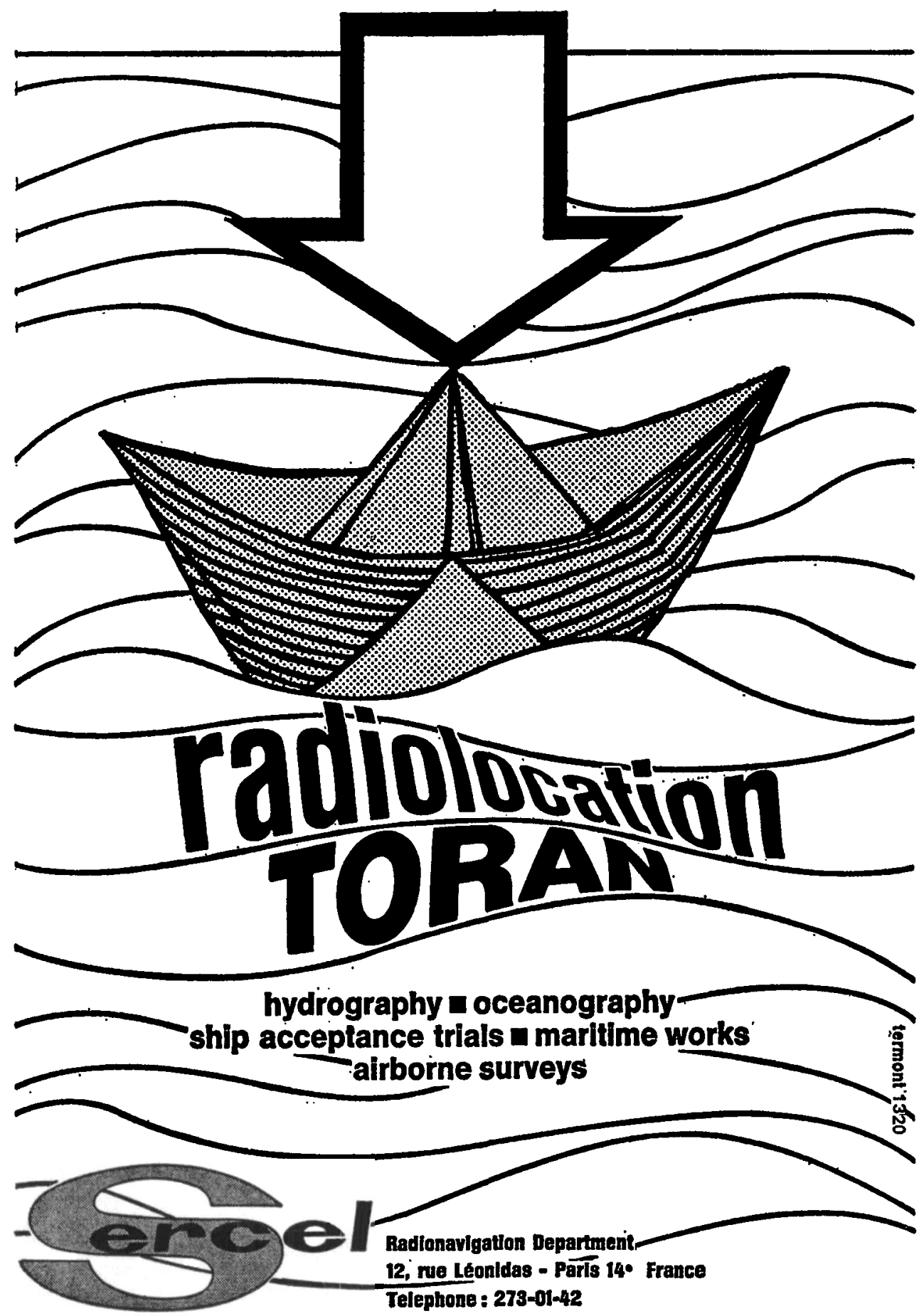




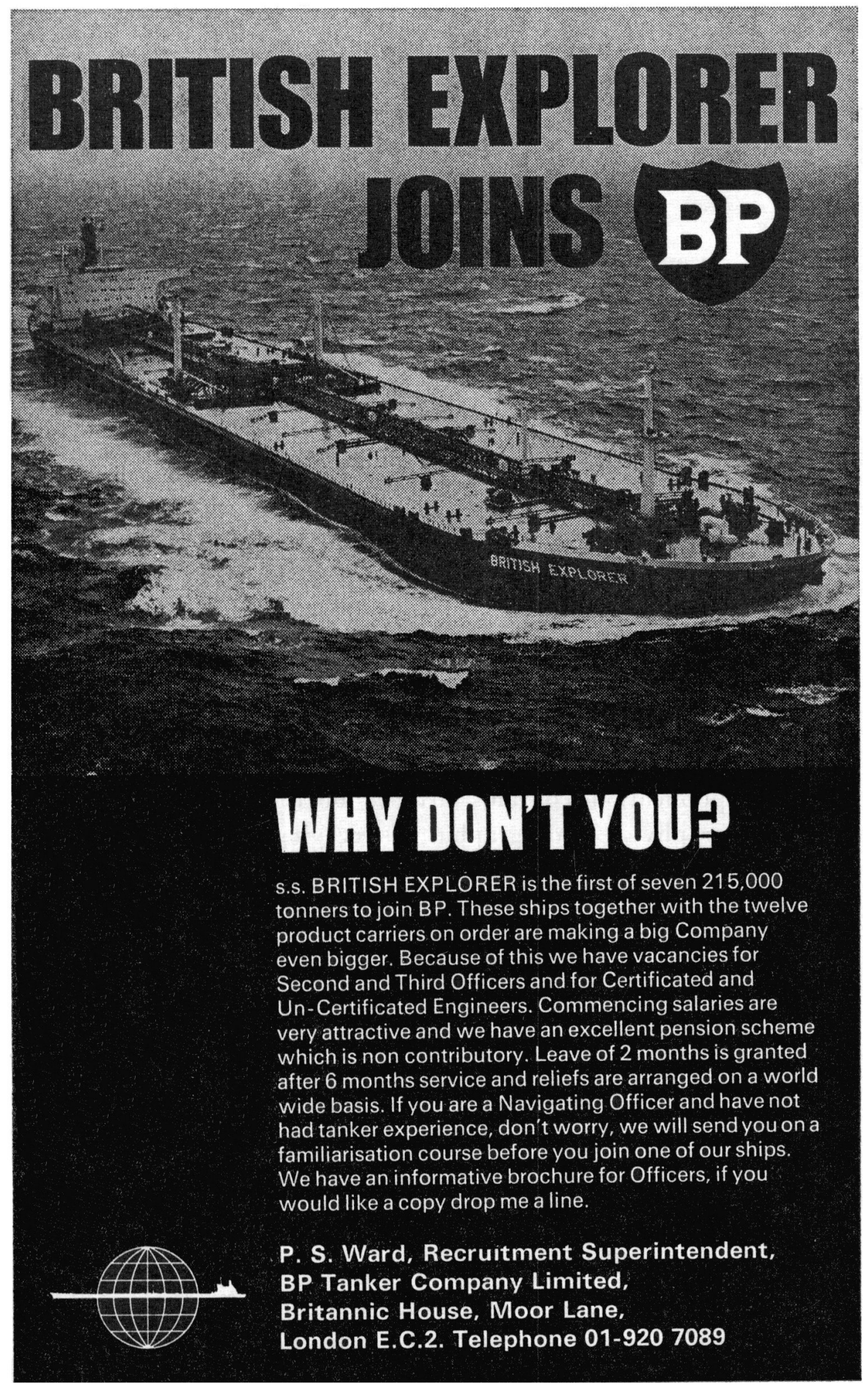




\title{
THE INTERNATIONAL HVDROGRAPHIC BUREAU
}

\section{Avenue Président J. F. Kenmedy, MONACO}

\author{
publishes
}

twice a year in Jannary and July, an English and a French eilition of

\section{THE INTERNATIONAL HYDROGRAPHIC REVIEW}

This publication contains articles of topical intcrest on bydrography, hydregraphic surveying and related subjects.

Each number contains an avcrage of 160 pages, $18 \times 27 \mathrm{~cm}$., and numerous illustrations.

Price per number 50/- or \$6 (U.S.), post free in Europe.

Orders should be sent direct to the Bureau's Headquarters in Monaco, but payments can be made to the Bureau's account at Barclays Bank Ltd., Chief Foreign Branch, 152-156 Upper Thames Strect, London, E.C.3. Specify English or French edition when ordering.

A reduction of $25 \%$ on the price quoted is allowed to booksellers. A reduction of $30 \%$ is granted to naval or merchant marine officers of the Bureau's Member States, provided the order is sent direct to the Burcau. 

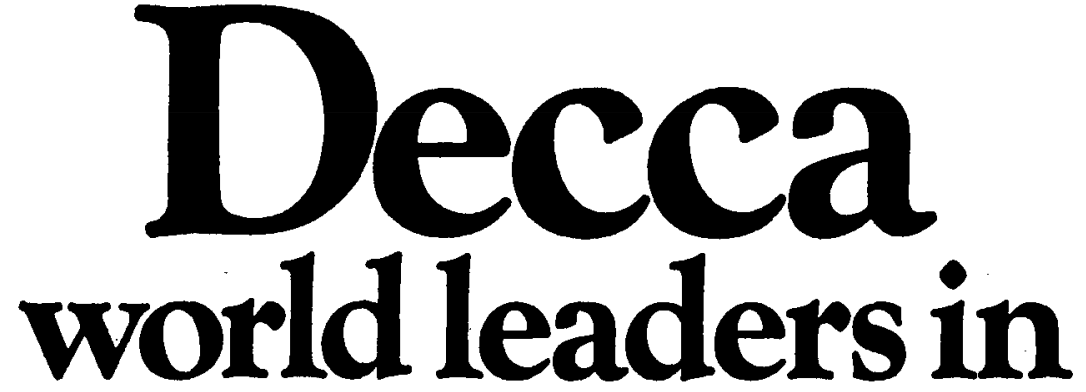

marine electronics

Decca Transar Radar

Decca ISIS 300 Integrated

Ship Instrumentation System

Decca Navigator System

Decca Arkas Automatic Pilot

Decca Radar Limited

The Decca Navigator Company Limited Decca House, Albert Embankment London SE1 40

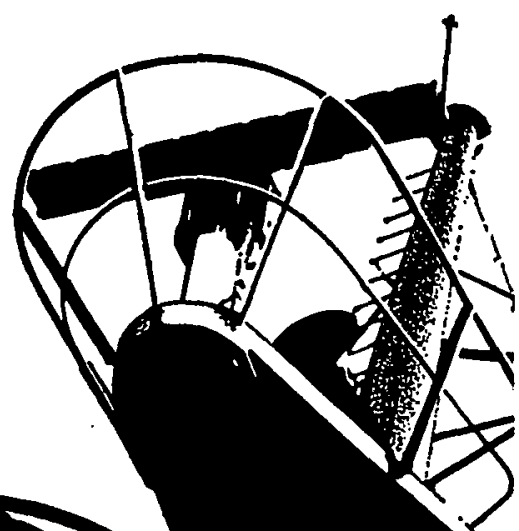



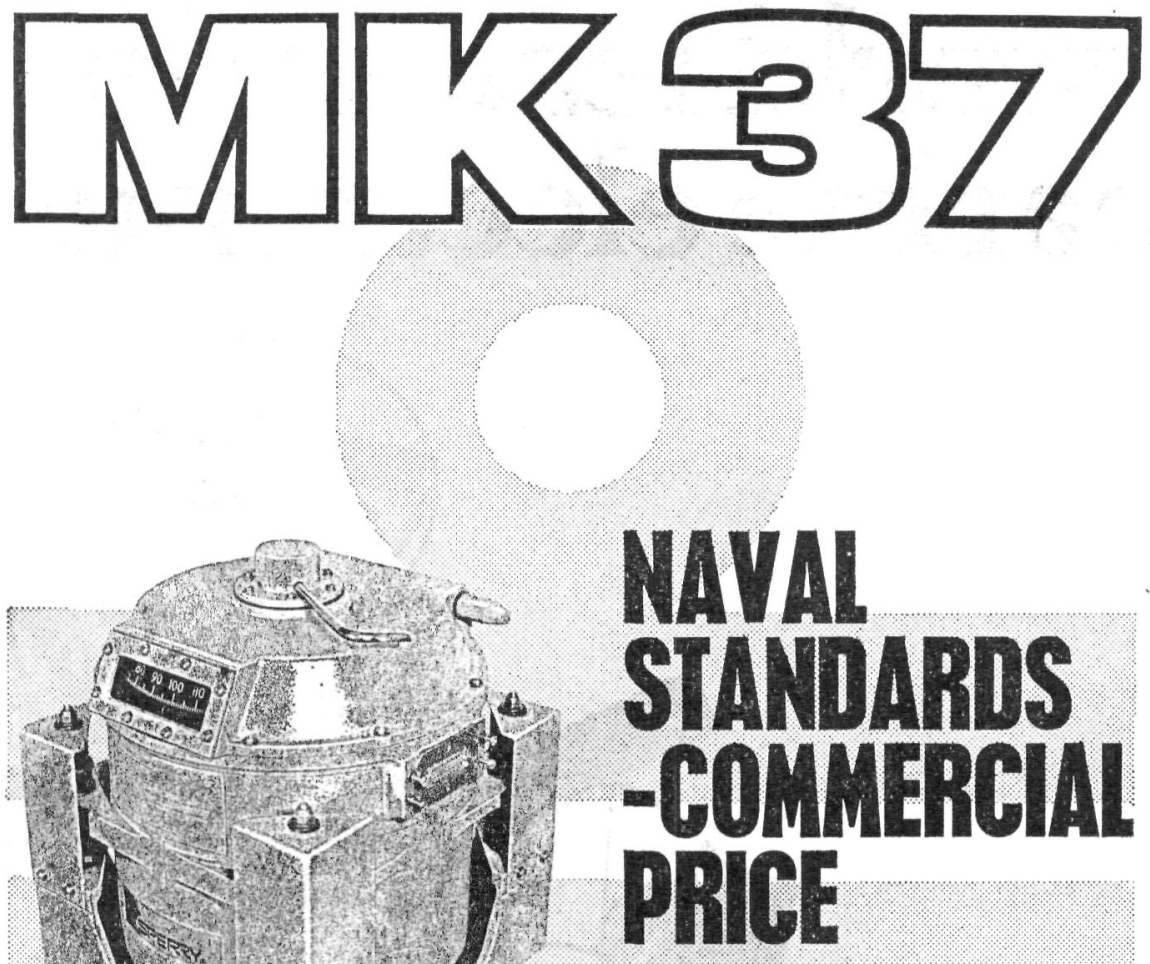

More than a thousand master units of the Sperry Mk37 Gyro Compass System have proved their reliability and accuracy in naval service.

This unique investment in experience, with obvious economies from large-batch production, enables Sperry to offer the owner and the shipyard unexcelled value for money.

The Mk37 is intended as the standard Sperry commercial compass system for the next decade of ocean-going vessels.

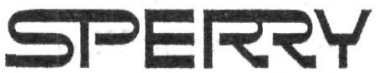

GYROSCOPE DIVISION

BRACKNELL BERKSHIRE ENGLAND 


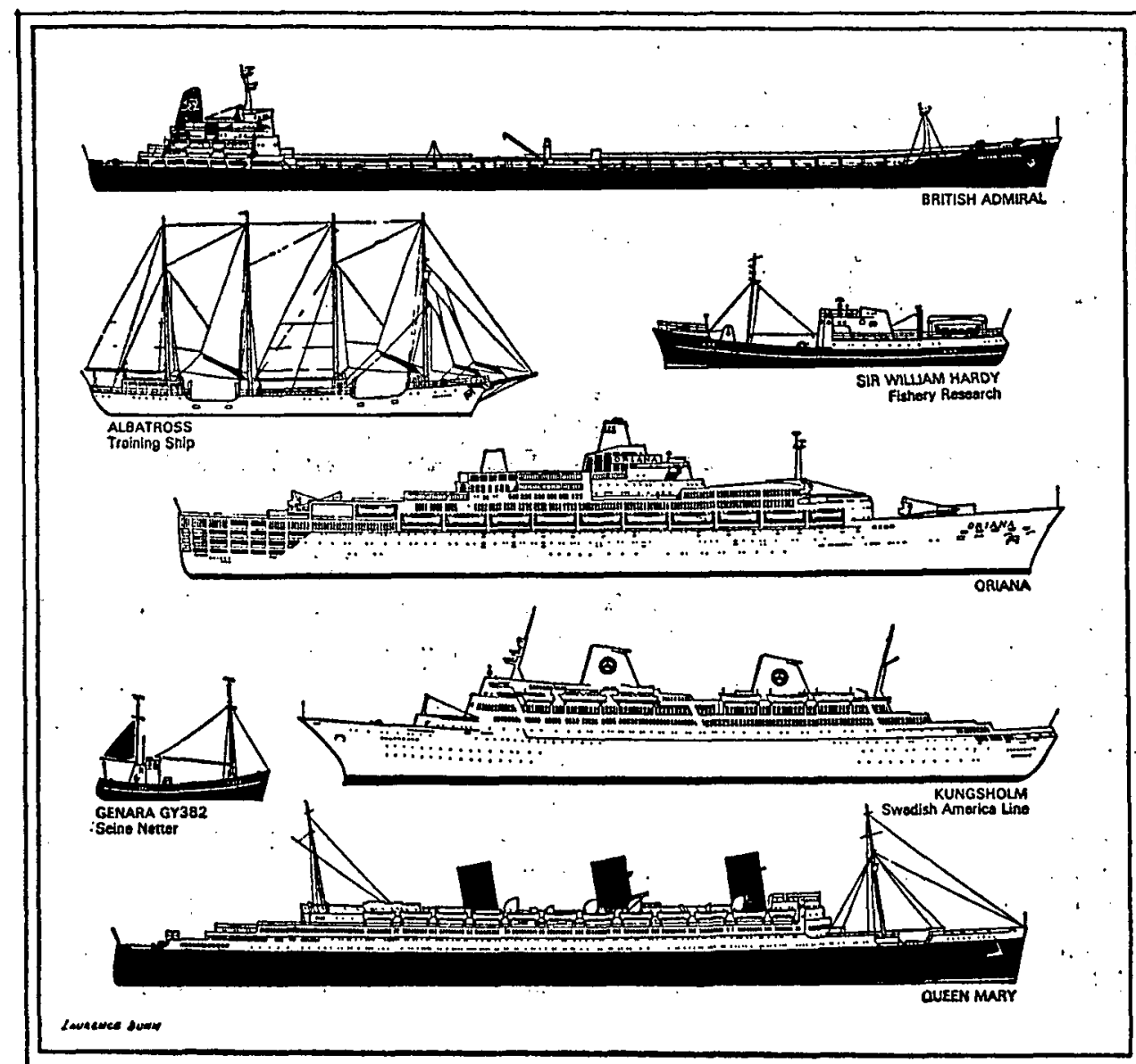

\section{A Growing Tradition...}

Over 15,000 ships of all types and sizes, from the largest supertankers to small fishing vessels, today rely on Decca for accurate navigation and economical operation. Now more and more ships will benefit even more widely as a result of the extensive new coverage now being set up in Australia, the Baltic; South Africa, Japan and the United States.

We are proud to be associated with the wide variety of famous, and not so famous, ships that have relied on the Decca Navigator since it was first introduced commercially over 20 years ago.

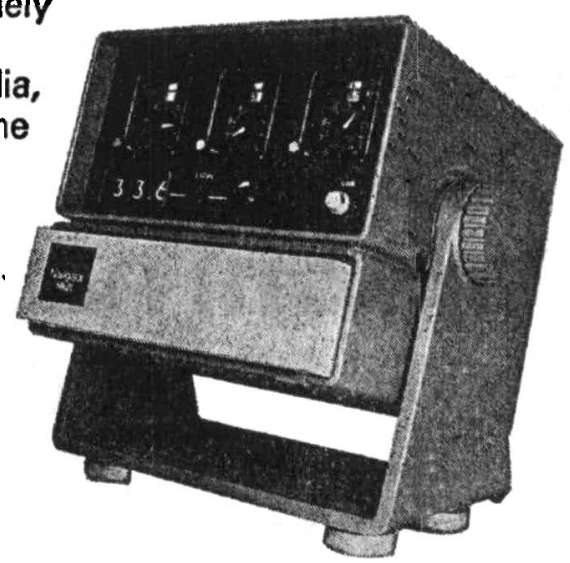




\section{Marconi \\ complete \\ naval}

communications

A complete range of communications equipment using s.s.b, i.s.b and all other modes of $h . f$ and $m . f$ transmissions, designed specifically for naval communications systems.

Simple, precise and highly accurate continuous decade selection of frequencies in $100 \mathrm{~Hz}$ steps.

- Rigid stability controlled by a single high accuracy frequency standard.
- Extreme simplicity of operation combined with versatility of service and high quality performance.

- Synthesizers and wideband amplifiers employed in these systems, which make maximum use of semiconductors.

- NATO codified.

- Complete system planning and installation.

This new range of Marconi equipment has already been used in the moderniza. tion of the communications of 10 Navies.

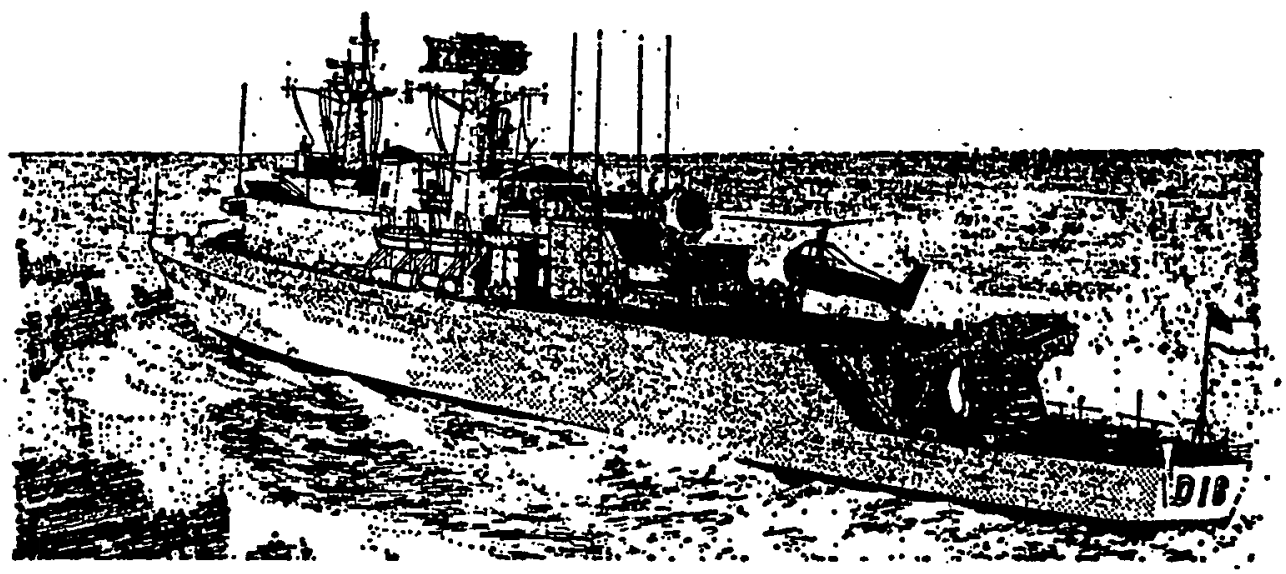

\section{Marconi naval radio and radar systems}

A GEC-Marconi Electronics Company

Marconi Communication Systems Limited, Radio Communications Division, Chelmsford, Essex 